\title{
Root morphological responses to population density vary with soil conditions and growth stages
}

\author{
Shu Wang ${ }^{1}$, Lei $\mathrm{Li}^{1}$, and Dao-Wei Zhou ${ }^{2}$ \\ ${ }^{1}$ Affiliation not available \\ ${ }^{2}$ Chinese Acad Sci
}

September 14, 2020

\begin{abstract}
How plants cope with the increase of population density via root plasticity is not well documented. Abiotic environments and plant ontogeny may play an important role in determining plant response to density and thus contribute to understanding this issue. We aimed to investigate root plasticity in response to density under contrasting soil conditions at three stages of plant growth in an annual herbaceous species Abutilon theophrasti. We conducted a field experiment by subjecting plant individuals to low, medium and high densities (13.4, 36.0 and 121.0 plants $\mathrm{m}-2$, respectively) under fertile and infertile soil conditions, and a series of root traits were measured at three harvests when they had grown for 30, 50 and 70 d. Results revealed the complexity of root response to density, which may increase, decrease or canalize, depending on the strength of above- and below-ground interactions, which varied with soil conditions or growth stage. The intensity of above- and/or below-ground interactions increased with decreased soil resources, but first increased then decreased with growth stage. Facilitation is more likely to occur at low to moderate below-ground interaction, when above-ground interaction is negligible, and resources are abundant and at early stage of plant growth. Plants may prefer to adjust biomass allocation to maintain total mass stable initially, before suffering decreased total mass, in response to intraspecific interactions.
\end{abstract}

\section{Introduction}

Population density, or competition, is one of major biotic environmental factors in nature. The increase of density can result in variations in multiple resources and plant-plant interactions (Casper et al.1997), affecting plant growth in many ways. However, the complexity of density effects is not well understood. Researches on effects of above- and below-ground competition separately (Cahill 2003, Murphy et al. 2007) or those of light quality or shade due to increased density (Bongers et al. 2018, Forster et al. 2011) contributed important information, but cannot help understanding how plants respond to density in an integrative perspective.

One aspect of the complicacy is the effects of abiotic environmental factors in plant response to density (Forster et al. 2011). Below-ground competition can be aggravated when below-ground resources limit plant growth (Casper and Jackson 1997, Schenk 2006). Increased soil resources can result in a shift in competition from occurring primarily below-ground to primarily above-ground (Tilman 1988, Wilsonet al. 1991), and an increased interaction between above- and below-ground competition (Cahill 1999). Consequently, soil conditions can significantly alter plant response to density (Poorter et al.2012). However, little evidence exists. A study showed above- and below-ground competition elicited independent responses, and the level of soil nutrient did not affect root response to the presence of neighbors (Murphy and Dudley 2007). Perhaps the low-nutrient regime did not cause true nutrient deficiencies, especially when competition was not intense. Substantial abiotic effects may result from effects of low vs. high levels of many resources, or infertile versus fertile soil conditions.

Another important aspect of the complicacy is temporal heterogeneity of density effects. For a dense pop- 
ulation, as plant sizes grow, competition intensity first increases then weakens (Hutchings et al. 1981). Moreover, from the perspective of allometric growth, a plant experiences significant changes in allocation pattern at various developmental phases (Harper et al. 1970, Weiner 2004). However, allometric analysis or removal of size effect within a single stage cannot eliminate ontogenetic effects, as plasticity of allometric relationships in response to density is stage dependent as well (Liet al. 2013). Therefore trait plasticity in response to density is expected to differ among stages, which may explain the inconsistency in relevant results.

Compared to above-ground responses, below-ground responses to density or competition received much less attention. Studies have mostly focused on root: shoot ratio or root mass allocation, producing inconsistent results: 1) neither above- nor below-ground competition alters root allocation (Cahill 2003, Casper et al. 1998); 2) interactions among plants enhance root: shoot ratio (Gersani et al. 2001, O'Brien et al. 2005); 3) root mass ratio is lower at high density relative to low density (Forster et al. 2011, Poorter et al. 2016, Poorter et al. 2012). The inconsistency may result from distinct density effects in different research systems, which vary in manipulation of density treatments, amounts of species, abiotic environments, and stages of plant growth etc., wherein plant growth stage and abiotic environments should be the most significant of all.

Finally, but not the least importantly, meta-analyses showed that lab grown plants experience different abiotic and biotic environments from those grow in fields, and have a much shorter time for growing, which may strongly affect a plant's overall morphology and physiology (Poorteret al. 2016). It is thereby necessary to apply growth regimes closer to field conditions for understanding density-induced plasticity that real occurs in nature (Gratani 2014, Poorter et al. 2016). Here we conducted a field experiment, growing plants of an annual species Abutilon theophrasti at different densities, under fertile versus infertile soil conditions, to measure a series of root traits at three stages of plant growth, in order to investigate whether and how plant root response to density can be altered by soil conditions and plant growth stage.

\section{Material and methods}

\section{Studied species}

Abutilon theophrasti Medicus (Malvaceae) is a native species to China and India, now spreads worldwide. It is an annual weedy species, erect with stout stems, usually can grow to a height of 1-1.5 m. Through rapid growth, it can reach reproductive maturity within $90 \mathrm{~d}$, and complete its life cycle in $\sim 5$ mo (McConnaughay et al. 1999), with substantial plasticity in allocation, morphology and architecture in response to varying environmental factors (McConnaughayet al. 1992). It colonizes relatively nutrient-rich habitats, being ubiquitous in open fields, on roadsides, and in gardens.

\section{Experimental design}

The experiment was conducted in 2007 at the Pasture Ecological Research Station of Northeast Normal University, Changling, Jilin province, China $\left(44^{\circ} 45^{\prime} \mathrm{N}, 123^{\circ} 45^{\prime} \mathrm{E}\right)$. Seeds were collected from local wild populations near the research station in late August 2006 and dry stored at $-4^{\circ} \mathrm{C}$. We used a split plot design, with soil conditions as the main factor, density and block as a sub-factor. Two large plots were assigned as two (Infertile and Fertile) soil conditions, each was divided into nine $2 \times 3 \mathrm{~m}$ sub-plots and randomly arranged with three treatments of densities and blocks. The treatment of infertile soil conditions as a plot was established using the original soil of experimental field at the station that had been used annually for many years (aeolian sandy soil), and the treatment of fertile soil conditions was set up by covering the other large plot with 5-10 cm virgin soil transported from a nearby meadow with no cultivation history (meadow soil), with contrasting nutrient contents of the two soil conditions (Wang et al. 2017). Seeds of $A$. theophrastiwere sown on June 7, 2007, with three inter-planting distances of 30, 20 and $10 \mathrm{~cm}$, to reach target plant densities of 13.4, 36 and 121 plants per $\mathrm{m}^{-2}$, assigned as Low, Medium and High density treatments respectively. Most seeds emerged $4 \mathrm{~d}$ after sowing. Seedlings were thinned to the target densities at four-leaf stage. Plots were hand-weeded when necessary and watered regularly.

Data collection 
Plants were harvested at 30,50 and $70 \mathrm{~d}$ of growth, representing developmental stages of early vegetative growth, late vegetative or early reproductive growth, and middle to late reproductive growth respectively. At each stage, six individual plants were randomly chosen from each plot, making a total of 6 replicates $\times$ 3 plots $\times 3$ densities $\times 2$ soils $\times 3$ stages $=324$ samplings. For each individual plant, the following traits were measured if applicable: diameter at the basal of the main root, length and number of lateral roots (above or equal to $1 \mathrm{~mm}$ in diameter along the main root). Morphological root traits were not measured at $30 \mathrm{~d}$ of growth due to small sizes of plants. Each individual was then separated into roots, stems, petioles, leaves, reproductive organs and branches (if any), enveloped respectively, and oven-dried at $75{ }^{\circ} \mathrm{C}$ for $2 \mathrm{~d}$ and weighed.

\section{Statistical analysis}

All statistical analyses were conducted using SAS statistical software (SAS Institute 9.0 Inc. 2002). Biomass traits including shoot mass, root mass, total biomass and root:shoot ratio, and morphological traits including main root length, main root diameter, lateral root number and lateral root length were analyzed. To minimize variance heterogeneity, all data were log-transformed before statistical analysis. Three-way ANOVA and ANCOVA were used to evaluate overall effects of growth stage, soil conditions and population density and their interactions on all traits, with total biomass nested in growth stage as a covariate in three-way ANCOVA. Within each soil condition at each stage, effects of density were analyzed by one-way ANOVAs for total mass, and one-way ANCOVAs for all the other traits with total mass as a covariate. For a given trait, it was considered to exhibit apparent plasticity whenever plant size (total biomass) accounted for significant variation in its response to density, and any variation in its expression that was independent of total biomass was considered an indication of true plasticity (after removal of size effects) (McConnaughay and Coleman 1999, Weiner 2004). Multiple comparisons used Least Significant Difference (LSD) method of the General Linear Model (GLM) program in one-way ANCOVA, which also produced adjusted mean values and standard errors.

\section{Results}

Growth stage, soil condition and population density had significant effects on total biomass and almost all other traits (Table 1). Interactions between stage and soil conditions, stage and density, soil conditions and density were also significant for most mass traits, stage and soil condition interaction were also significant for most morphological traits. Except for root: shoot ratio and lateral root length, plant size (or total biomass) accounted for a significant amount of variations in all traits.

Total biomass was decreased by infertile vs. fertile soil, and by the increase of density in both soil conditions at all stages except for those of $30 \mathrm{~d}$-growth in fertile soil (Fig. 1). At $30 \mathrm{~d}$ of growth, neither soil condition nor population density affected total biomass, but effects of density on shoot mass and root mass were significant in fertile soil, though a large fraction of these variations were due to effects of plant size (Table 2).

After removal of size effect, effects of stage, soil, density, and stage and soil interactions were still significant for most traits (Table 1). A greater number of traits responded to density in infertile vs. fertile soil at $50 \mathrm{~d}$ and $70 \mathrm{~d}$ (Table 2). True plasticity occurred in all traits except main root length in response to density, and responses of these traits varied with soil conditions and/or growth stages (Table 2; Fig. 2-4). Density effect on main root length was significant in three-way ANCOVA, but not in one-way ANCOVA under either soil conditions at any stage, indicating apparent plasticity (Table 2).

At $30 \mathrm{~d}$ of growth, plant individuals in fertile soil conditions had lower shoot mass, higher root mass and root: shoot ratio at medium and high density, compared to at low density $(\mathrm{p}<0.05)$, but not in infertile soil (Fig. 1,2). Under infertile soil, high density enhanced shoot mass, reduced root mass and root: shoot ratio at $50 \mathrm{~d}(\mathrm{p}<0.01)$; medium and high density enhanced shoot mass at $70 \mathrm{~d}(\mathrm{p}<0.05)$; no significant response to density was found under fertile soil at the two stages. For morphological traits, lateral root length decreased with higher densities under both soil conditions $(\mathrm{p}<0.01)$, but main root diameter was decreased by high density in infertile soil only $(\mathrm{p}<0.05)$ at both stages (Fig. 3). High density also reduced lateral root number, compared to that at low density $(\mathrm{p}=0.002)$, for 50 d-growth individuals in infertile soil. 


\section{Discussion}

Although root morphological traits generally decreased, root mass allocation increased, decreased or canalized, with increased density, depending on different soil conditions and growth stages. These suggested the responses of plant roots to density is not merely a single or simple reaction, but of complexity, including multiple responsive trends within and among traits. Density effects included effects of above- and belowground interactions respectively, the strength of which can vary with soil conditions and growth stage in actuality. The response of plant total mass mainly reflected the passive effects of intraspecific interactions and its intensity, while responses of root:shoot ratio and root morphological traits explicitly revealed the strategies of plants in dealing with such biotic environmental effects (plant active reactions).

Due to the complexity of results, we used a table to illustrate this issue, by classifying plant response to density into three circumstances (Table 3): (a) response to below-ground interaction only (when above-ground interaction is negligible), (b) response to above-ground interaction only (when below-ground interaction is negligible), and (c) response to both kinds of interactions or response to density (effects of both interactions are not negligible). Within each circumstance, the intensity of above- or (and) below-ground interactions can be estimated as low $(\mathrm{L})$, moderate $(\mathrm{M})$ or high $(\mathrm{H})$ level according to the response of plant total mass. To reinforce our conclusions, we also cited results from other studies in each circumstance.

\section{Response to below-ground interaction only}

In our study, at the first stage, plants were not large and branchy enough to interfere each other above ground, thus they should have mainly experienced below-ground interactions, with negligible above-ground interactions. During this period, we found no response in total mass and two kinds of responses in root: shoot ratio under two soil conditions respectively (Fig. 1 and Table 3a): (1) increased root: shoot ratio with higher densities in fertile soil; (2) canalized root: shoot ratio in infertile soil. When total mass did not respond to interaction, we consider it experienced low level of interaction. In this scenario, response of root allocation to below-ground interaction varied with soil conditions.

Plant-plant interaction can produce either competitive or facilitative results (Callaway 2007, Callaway et al. 1997), depending on plant growth stages or stress levels (Callaway 1995, Callaway et al.2000, Callaway and Walker 1997). Soil conditions may affect root responses via modifying the intensity of below-ground interaction. Low to moderate level of interaction is more likely to produce facilitative effects (Casper and Jackson 1997), as in studies of Gersani et al. and O'Brien et al. (Gersani et al. 2001, O'Brien et al. 2005). It also implied facilitative effects of below-ground interaction can only be detected when above-ground interaction is negligible, which usually occurs at early stage of plant growth and when resources are abundant. Increased root allocation in response to density in fertile soil at 30 days of plant growth in this study suggested a facilitative effect of below-ground interaction. By contrast, no response in root allocation in infertile soil suggested below-ground interactions were not strong enough to affect root allocation, or otherwise facilitative effect was counteracted by competition, which was aggravated due to resource deficiency. As resource availability decreased, intensity of below-ground competition generally increases (Cahill 1999, Casper and Jackson 1997, Schenk 2006). We also found a decrease in root:shoot ratio by intraspecific interaction in dry soil, though response of total mass indicated facilitation. It suggested water deficiency may intensify below-ground competition, leading to decreased root allocation, even when the overall result of interaction is facilitative.

No significant facilitative effects on total mass may be explained by a shift of plant strategy in dealing with environmental stress. For example, under plant-plant interaction, plants may prefer to alter biomass allocation at first, then alter total mass as interaction intensity increases. As interaction intensity continued to increase, total mass can decreased at high level of interaction, when root:shoot ratio responded to interaction (Li et al. 2016) or kept stable (Cahill 2003). As plants grew larger, the strength of competition first increased then decreased (Hutchings and Budd 1981). Plants in fertile soil first altered biomass allocation then kept it stable, due to the attenuation of interaction intensity (Wang et al. 2017). However, we do not know why root allocation increased with interaction in this situation ( $\mathrm{Li}$ et al. 2016). Of course, the intensity of below- 
ground interaction can also be affected by a variety of other factors, such as pot space, number of neighbors (or growing density), sizes of species (due to age or genetic nature), thus we also referred to information on these factors.

\section{Response to above-ground interaction only}

Our study did not include results on response to above-ground interaction only. To interpret this issue more explicitly, however, we quoted results from light-effect studies (Table 3b), which simulated density effects via manipulating variations in light quantity and quality. Although light signals cannot completely equate to above-ground interaction, but these results provided essential information, which is difficult to acquire using density or interaction treatments, especially when plants are expected to grow in more nature or normal state.

From these results, we found above-ground interactions can had no effects at low to moderate levels, or had stronger negative effects on root allocation (Table 3b) than below-ground interactions (Table 3a). Light competition may not affect total mass and root allocation at low intensity (Murphy and Dudley 2007), or decrease them at high intensity (Kennedy et al. 2007). Similarly as below-ground interaction, the strength of above-ground interaction may first increase then decrease over time (Hutchings and Budd 1981, Wang et al. 2017). And plants interacting with neighbors may alter biomass allocation while maintaining total mass at first, then alter total mass as interaction intensifies. When total mass did not respond to light while root allocation decreased (Forster et al. 2011), it suggested above-ground interaction was getting increasingly intense and began to affect root allocation, but not strong enough to affect total mass. No response in root allocation and a decrease in total mass indicated attenuated above-ground interaction (Casper et al. 1998). It is interesting to note that root mass allocation in shade was lower than that in full light, but unaffected by density (Table 3b, 3c; Forsteret al. 2011), suggesting the decrease of root allocation by above-ground interaction can be alleviated by facilitative effects of below-ground interactions in dense population .

\section{Response to density}

As plants grew large enough, both above- and below-ground interactions occurred, plant root response to density may actually depend on the relative strength of competition vs. facilitation. When competition became intense enough to counteract or surpass facilitative effects, increased density either did not affect root allocation (Forsteret al. 2011), or decreased root allocation (Maliakal et al. 1999), depending on resource levels (Table 3c). Nutrient depletion can intensify below-ground competition (Tilman 1988, Wilson and Tilman 1991). As below-ground resources decreased, competition among plants transformed from primarily above-ground to primarily below-ground (Grime 1973, Grime 1979). Consequently, when a plant in dense population suffers resource deficiency, its root allocation is more likely decreased, due to intensified belowground competition primarily, as the case in infertile soil conditions at 50 days of plant growth in this study. Otherwise, sufficient resources may alleviate below-ground competition, leading to no response to density in roots, such as in fertile soil at the same stage in this study. However, no response to density in root allocation also occurred in infertile soil at 70 days of growth, suggested interaction intensity first increases then decreases over time (Hutchings and Budd 1981, Wang et al. 2017).

\section{Relationships between root and leaf responses}

Comparing response to density in root and leaf allocation, we found an attenuated decrease in root allocation by density and an intensified decrease in leaf allocation from $50 \mathrm{~d}$ to $70 \mathrm{~d}$ in infertile soil, and with better soil conditions at $50 \mathrm{~d}$ (Wang et al. 2017). It implied a trade-off relationship between responses of the two modules. The mass accumulation of stem is important for its elongation and leaf positioning, thus determining plant competition advantage. Therefore the increment of root mass cannot be at the cost of stem mass but of leaf mass at vegetative stage, determining the negative relationship between responses of roots and leaves.

It is reported a positive relationship exists between below- and above-ground competition under fertilized condition (Cahill 1999). Inconsistent results may be caused by different methodologies in study systems. In competition studies, competition intensity and plant response were usually estimated by referring to 
plant above-ground performance only, regardless of below-ground performance (Cahill 1999, Gaucherand et al. 2006). However, in plasticity studies, we often considered root, leaf and stem traits respectively, which indeed differed substantially in response to neighbors. Further evidence for the relationship between aboveand below-ground competitions can be provided by relevant studies via calculating responses of both aboveand below-ground modules.

\section{Responses of different root traits}

Different root morphological traits differed in response to density: those mainly amplify into horizontal space such as lateral root length and number, and main root diameter, were more likely to decline with increased density, while those expands primarily into greater depth such as main root length unaffected. These implied an effect of spatial orientation of density on root propagation: the presence of neighbor tended to restrict its expansion horizontally rather than vertically (Gundel et al. 2014). For example, high density increased roots of apple (Malus sp.) into deeper rather than upper soil layers (Atkinson et al. 1976), similar to other results (Mason et al. 1982, Pearson et al. 1985). Belowground modules of bulb that enlarge horizontally were decreased by high density, but not for roots that grow into greater depths (Li et al. 2011).

The presence of neighbors in the horizontal space may have reduced nutrients available, making it is inefficient to forage a greater range for satisfactory resources (Semchenko et al. 2007). Therefore, as long as the deeper space is available, it is more intelligent to expand roots into greater depth to acquire resources, than scrambling for the deficient upper-soil resources (Gundel et al. 2014). Such spatial-orientation effects of density can also be proved by alleviated reduction by density in lateral root traits in fertile vs. infertile soil. When inefficient root placement cannot be avoided, as plants grown in pots with small depth, reproductive growth will inevitably decline, exactly as in the phenomenon of 'tragedy of commons' (Gersani et al. 2001). Due to the costs of producing plasticity, an extra root proliferation will be costly itself. If it brings no benefits at all, or sheer expenditure without subsequent income, plants will be unable to maintain reproductive growth.

\section{Conclusions}

In conclusion, plant root growth may increase, decrease or canalize, in response to the increase of density, depending on the strength of above- and below-ground interactions, which can vary with soil conditions and plant growth stage. (1) As interaction intensity increases, plants first alter biomass allocation to keep plant size stable, then suffer a reduction of plant size. Low to moderate below-ground interaction is more likely to facilitate root growth, but the effects fade away when interaction is intense; above-ground interaction mainly induce negative root response at high intensity. (2) Soil conditions altered root response mainly through effects on below-ground interactions, growth stage affected root response mainly through effects on plant size and both kinds of interactions. (3) By comparing root and leaf responses to density, we found a negative relationship between them. It shed light on the necessity of considering both below-ground and various above-ground modules in competition studies. (4) Increased density was more likely to restrict root growth horizontally than vertically. It is more efficient for plants to forage greater depth for resources, than competing for the deficient resources in upper soil.

The study underscored the important roles of abiotic environmental factors and plant ontogeny in determining plant response to biotic environmental factor, which may at least partly explain the inconsistent results in relevant studies. The complexity of plant response to density can be better understood under different backgrounds of abiotic factors and plant ontogenetic stages.

\section{Acknowledgements}

We thank Ping Wang, Guang-Di Li, Yue-Jun He, Guang-Qi Zhang and Shi-Xiong Wang for comments and advice on earlier versions of the paper, and Bao-Tian Zhang and other staff at the research station for assistance in managing our experiment. This work was supported by the National Natural Science Foundation of China (NSFC, grant number 31800335), and Guizhou Province Science and Technology Planning Program 
([2019]1089), NSFC-Cultivation-Program Priority Funding Program (2017-5788), Ecology Domestic FirstClass Discipline Construction Program (GNYL2017-007) to S.W..

\section{Data Accessibility}

- Sampling morphological data: Dryad doi: 10.5061/dryad.ngf1vhhs2

\section{References}

Atkinson D, Naylor D, Coldrick GA (1976) The effect of tree spacing on the apple root system.Horticultural Research $16: 89-105$.

Bongers FJ, Pierik R, Anten NPR, Evers JB (2018) Subtle variation in shade avoidance responses may have profound consequences for plant competitiveness. Annals of Botany121 :863-873.

Cahill Jr JF (1999) Fertilization effects on interactions between above- and belowground competition in an old field. Ecology 80 :466-480.

Cahill Jr JF (2003) Lack of relationship between below-ground competition and allocation to roots in 10 grassland species. Journal of Ecology 91 :532-540.

Callaway RM (1995) Positive interactions among plants. Botanical Review 61 :306-349.

Callaway RM (2007) Positive interactions and interdependence in plant communities, New York: Springer, 415 .

Callaway RM, Pennings SC (2000) Facilitation may buffer competitive effects: Indirect and diffuse interactions among salt marsh plants. American Naturalist156 :416-424.

Callaway RM, Walker LR (1997) Competition and facilitation: A synthetic approach to interactions in plant communities. Ecology 78 :1958-1965.

Casper BB, Cahill Jr JF, Hyatt LA (1998) Above-ground competition does not alter biomass allocated to roots in Abutilon theophrasti . New Phytologist140:231-238.

Casper BB, Jackson RB (1997) Plant competition underground. Annual Review of Ecology and Systematics $28: 545-570$.

Forster MA, Ladd B, Bonser SP (2011) Optimal allocation of resources in response to shading and neighbours in the heteroblastic species, Acacia implexa. Annals of Botany 107 :219-228.

Gaucherand S, Liancourt P, Lavorel S (2006) Importance and intensity of competition along a fertility gradient and across species. Journal of Vegetation Science $17: 455-464$.

Gersani M, Brown JS, Brien EO, Maina GM, Abramsky Z (2001) Tragedy of the commons as a result of root competition. Journal of Ecology 89 :660-669.

Gratani L (2014) Plant phenotypic plasticity in response to environmental factors. Advances in Botany 2014 $: 1-47$.

Grime JP (1973) Competitive exclusion in herbaceous vegetation. Nature 242 :344-347.

Grime JP (1979) Plant strategies and vegetation processes, Chichester: Wiley.

Gundel PE, Pierik R, Mommer L, Ballaré CL (2014) Competing neighbors: Light perception and root function. Oecologia $176: 1-10$.

Harper JL, Ogden J (1970) The reproductive strategy of higher plants. I. The concept of strategy with special reference to Senecio vulgaris 1. Journal of Ecology 58 :681-698.

Hutchings MJ, Budd CSJ (1981) Plant competition and its course through time. BioScience31 :640-645. 
Kennedy S, Black K, O'Reilly C, Dhubhain AN (2007) The impact of shade on morphology, growth and biomass allocation in Picea sitchensis, Larix eurolepis and Thuja plicata. New Forests 33 :139-153.

Li L, Weiner J, Zhou D, Huang Y, Sheng L (2013) Initial density affects biomass-density and allometric relationships in self-thinning populations of fagopyrum esculentum. Journal of Ecology 101 :475-483.

Li L, Zhou D, Sheng L (2011) Density dependence-determined plant biomass allocation pattern. Chinese Journal of Ecology $30: 1579-1589$.

Li P-F, Ma B-L, Yan W, Cheng Z-G, Li F-M, Xiong Y-C (2016) Plant architecture, plasticity, and adaptation strategies of two oat genotypes under different competition intensities. Journal of Food Agriculture 96 :14311439 .

Maliakal SK, McDonnell K, Dudley SA, Schmitt J (1999) Effects of red to far-red ratio and plant density on biomass allocation and gas exchange in Impatiens capensis .International Journal of Plant Sciences $\mathbf{1 6 0}$ :723-733.

Mason WK, Rowse HR, Bennie ATP, Kaspar TC, Taylor HM (1982) Responses of soybeans to two row spacings and two soil water levels. Ii. Water use, root growth and plant water status. Field Crops Research $5: 15-29$.

McConnaughay KDM, Bazzaz FA (1992) The occupation and fragmentation of space: Consequences of neighbouring shoots. Functional Ecology 6 :711-718.

McConnaughay KDM, Coleman JS (1999) Biomass allocation in plants: Ontogeny or optimality? A test along three resource gradients. Ecology 80 :2581-2593.

Murphy GP, Dudley SA (2007) Above- and below-ground competition cues elicit independent responses. Journal of Ecology 95 :261-272.

O'Brien EE, Gersani M, Brown JS (2005) Root proliferation and seed yield in response to spatial heterogeneity of below-ground competition. New Phytologist168:401-412.

Pearson CJ, Jacobs BC (1985) Root distribution in space and time in Trifolium subterranean .Australian Journal of Agricultural Research 36 :601-614.

Poorter H, Fiorani F, Pieruschka R, Wojciechowski T, Putten WHvd, Kleyer M, Schurr U, Postma J (2016) Pampered inside, pestered outside? Differences and similarities between plants growing in controlled conditions and in the field New Phytologist $212: 838-855$.

Poorter H, Niklas KJ, Reich PB, Oleksyn J, Poot P, Mommer L (2012) Biomass allocation to leaves, stems and roots: Meta-analyses of interspecific variation and environmental control. New Phytologist 193 :30-50.

Schenk HJ (2006) Root competition: Beyond resource depletion. Journal of Ecology 94 :725-739.

Semchenko M, Hutchings M, John E (2007) Challenging the tragedy of the commons in root competition: Confounding effects of neighbour presence and substrate volume. Journal of Ecology 95 :252-260.

Tilman D (1988) Plant strategies and the dynamics and structure of plant communities, Princeton, NJ, USA: Princeton University Press.

Wang S, Li L, Zhou D-W (2017) Morphological plasticity in response to population density varies with soil conditions and growth stage in abutilon theophrasti(malvaceae). Plant Ecology 218 :785-797.

Weiner J (2004) Allocation, plasticity and allometry in plants. Perspectives in Plant Ecology, Evolution and Systematics 6 :207-215.

Wilson SD, Tilman D (1991) Components of plant competition along an experimental gradient of nitrogen availability. Ecology 72 :1050-1065. 
Table 1. Three-way ANOVAs on log-transformed total biomass (TM) and ANCOVAs on log-transformed root traits, with growth stage (GS), soil conditions (SC), and population density (PD) as effects, and $\log _{10}(\mathrm{TM})$ as a covariate in ANCOVA.

\begin{tabular}{llll}
\hline Trait & N & TM & Gs \\
Across all three stages & Across all three stages & Across all three stages & A \\
Df & & 1 & 26 \\
TM & 282 & & 13 \\
SM & 282 & $6784.72^{* * *}$ & 15 \\
RM & 282 & $4938.17^{* * *}$ & 24 \\
R/S & 282 & 1.32 & $\mathbf{A}$ \\
Across two stages of 50 and $\mathbf{7 0} \mathbf{d}$ & Across two stages of $\mathbf{5 0}$ and $\mathbf{7 0 ~ d}$ & Across two stages of $\mathbf{5 0}$ and $\mathbf{7 0 ~ d ~}$ \\
Df & & 1 & 13 \\
TM & 199 & $5.51^{* *}$ & 54 \\
MRL & 199 & $131.22^{* * *}$ & 86 \\
MRD & 199 & 0.73 & 57 \\
LRL & 199 & $38.97^{* * *}$ & 7. \\
LRN & 199 & & 2 \\
\hline
\end{tabular}

RM: root mass; SM: shoot mass; R/S: root: shoot ratio; MRL: main root length; MRD: main root diameter; LRL: lateral root length; LRN: lateral root number. Significance levels were: ${ }^{*} \mathrm{p}<0.05,{ }^{* *} \mathrm{p}<0.01,{ }^{* * *}$ $\mathrm{p}<0.001$.

+ Total biomass, shoot mass, root mass and root: shoot ratio were analyzed with data across all three stages (282 individuals in total), and other traits across two stages of 50 and $70 \mathrm{~d}$ (199 individuals).

Table 2. F values for one-way ANOVAs on log-transformed total biomass (TM) and ANCOVAs on logtransformed root traits, with population density (PD) as effect in two soil conditions at 30,50 and $70 \mathrm{~d}$ of growth, and $\log _{10}(\mathrm{TM})$ nested within growth stage as a covariate in ANCOVAs.

\begin{tabular}{|c|c|c|c|c|c|c|}
\hline Trait & $\begin{array}{l}\text { Infertile soil } \\
\mathrm{N}\end{array}$ & $\begin{array}{l}\text { Infertile soil } \\
\text { TM }(\text { Df }=1)\end{array}$ & $\begin{array}{l}\text { Infertile soil } \\
\mathrm{PD}(\mathrm{Df}=2)\end{array}$ & $\begin{array}{l}\text { Fertile soil } \\
\mathrm{N}\end{array}$ & $\begin{array}{l}\text { Fertile soil } \\
\text { TM }(\text { Df }=1)\end{array}$ & $\begin{array}{l}\text { Fertile soil } \\
\text { PD }(\text { Df }=2)\end{array}$ \\
\hline $30 \mathrm{~d}$ & $30 \mathrm{~d}$ & & & & & \\
\hline $\mathrm{TM}$ & 37 & & 1.69 & 46 & & 2.64 \\
\hline SM & 37 & $3479.65^{* * *}$ & 1.57 & 46 & $13194.4^{* * *}$ & $3.62^{*}$ \\
\hline $\mathrm{RM}$ & 37 & $79.05^{* * *}$ & 1.34 & 46 & $39.57 * * *$ & 2.79 \\
\hline $\mathrm{R} / \mathrm{S}$ & 37 & 0.15 & 1.37 & 46 & $21.47^{* * *}$ & 2.87 \\
\hline $50 \mathrm{~d}$ & $50 \mathrm{~d}$ & & & & & \\
\hline TM & 49 & & $39.40 * * *$ & 53 & & $13.98^{* * *}$ \\
\hline $\mathrm{SM}$ & 49 & $11954.6^{* * *}$ & $11.98 * * *$ & 53 & $22725.7^{* * *}$ & 2.27 \\
\hline RM & 49 & $96.34^{* * *}$ & $7.45 * *$ & 53 & $451.34^{* * *}$ & 2.34 \\
\hline $\mathrm{R} / \mathrm{S}$ & 49 & 1.00 & $7.98^{* *}$ & 53 & 0.06 & 2.35 \\
\hline MRL & 49 & $19.24^{* * *}$ & 1.80 & 53 & $10.68^{* *}$ & 3.26 \\
\hline MRD & 49 & $269.48^{* * *}$ & $4.74^{*}$ & 53 & $447.95^{* * *}$ & 0.41 \\
\hline LRL & 49 & $16.64^{* * *}$ & $13.25^{* * *}$ & 53 & $56.20^{* * *}$ & $8.57 * * *$ \\
\hline LRN & 42 & $21.44^{* * *}$ & $8.53^{* * *}$ & 53 & $52.16^{* * *}$ & 1.48 \\
\hline $70 \mathrm{~d}$ & $70 \mathrm{~d}$ & & & & & \\
\hline TM & 51 & & $9.17 * * *$ & 46 & & $19.83^{* * *}$ \\
\hline SM & 51 & $1515.25^{* * *}$ & $3.31 *$ & 46 & $3697.80^{* * *}$ & 2.38 \\
\hline $\mathrm{RM}$ & 51 & $176.49^{* * *}$ & 1.89 & 46 & $87.67 * * *$ & 1.53 \\
\hline $\mathrm{R} / \mathrm{S}$ & 51 & 0.00 & 1.49 & 46 & 0.46 & 1.59 \\
\hline MRL & 51 & 0.01 & 2.83 & 46 & 1.19 & 0.46 \\
\hline
\end{tabular}




\begin{tabular}{|c|c|c|c|c|c|c|}
\hline MRD & 51 & $19.89^{* * *}$ & $4.16^{*}$ & 46 & $161.14^{* * *}$ & 1.64 \\
\hline LRL & 51 & $18.39^{* * *}$ & $15.45 * * *$ & 46 & 0.98 & $11.52^{* *}$ \\
\hline LRN & 51 & $34.58^{* * *}$ & $6.23 * *$ & 46 & $45.90^{* * *}$ & 0.80 \\
\hline
\end{tabular}

$\mathrm{N}$ represents the number of individual values for each trait in each soil and stage combination. SM: shoot mass; RM: root mass; R/S: root: shoot ratio; MRL: main root length; MRD: main root diameter; LRL: lateral root length; LRN: lateral root number. Significance levels were: ${ }^{*} \mathrm{p}<0.05,{ }^{* *} \mathrm{p}<0.01,{ }^{* * *} \mathrm{p}<$ 0.001 .

Table 3. Results and information of experimental treatments for present study and other studies, showing responses of root: shoot ratio or root mass ratio to (a) below-ground interaction only; (b) above-ground interaction only; and (c) below-, above-ground interactions or population density.

\begin{tabular}{|c|c|c|c|c|c|c|c|c|c|}
\hline $\begin{array}{l}\text { Shoot } \\
\text { mass }^{a}\end{array}$ & $\begin{array}{l}\text { Root } \\
\text { mass }\end{array}$ & $\begin{array}{l}\text { Root:shoot } \\
\text { ratio }\end{array}$ & $\begin{array}{l}\text { Total } \\
\text { mass }\end{array}$ & $\begin{array}{l}\text { Interaction } \\
\text { intensity }\end{array}$ & $\begin{array}{l}\text { Growth } \\
\text { space }^{b}\end{array}$ & $\begin{array}{l}\text { Density } \\
\text { treatment }^{c}\end{array}$ & $\begin{array}{l}\text { Soil } \\
\text { conditions }\end{array}$ & $\begin{array}{l}\text { Growth } \\
\text { stage }\end{array}$ & Species \\
\hline $\begin{array}{l}\text { a. Re- } \\
\text { sponse } \\
\text { to }\end{array}$ & $\begin{array}{l}\text { a. Re- } \\
\text { sponse } \\
\text { to }\end{array}$ & $\begin{array}{l}\text { a. Re- } \\
\text { sponse } \\
\text { to }\end{array}$ & $\begin{array}{l}\text { a. Re- } \\
\text { sponse } \\
\text { to }\end{array}$ & $\begin{array}{l}\text { a. Re- } \\
\text { sponse } \\
\text { to }\end{array}$ & $\begin{array}{l}\text { a. Re- } \\
\text { sponse } \\
\text { to }\end{array}$ & $\begin{array}{l}\text { a. Re- } \\
\text { sponse } \\
\text { to }\end{array}$ & $\begin{array}{l}\text { a. Re- } \\
\text { sponse } \\
\text { to }\end{array}$ & $\begin{array}{l}\text { a. Re- } \\
\text { sponse } \\
\text { to }\end{array}$ & $\begin{array}{l}\text { a. Re- } \\
\text { sponse } \\
\text { to }\end{array}$ \\
\hline $\begin{array}{l}\text { below- } \\
\text { ground }\end{array}$ & $\begin{array}{l}\text { below- } \\
\text { ground }\end{array}$ & $\begin{array}{l}\text { below- } \\
\text { ground }\end{array}$ & $\begin{array}{l}\text { below- } \\
\text { ground }\end{array}$ & $\begin{array}{l}\text { below- } \\
\text { ground }\end{array}$ & $\begin{array}{l}\text { below- } \\
\text { ground }\end{array}$ & $\begin{array}{l}\text { below- } \\
\text { ground }\end{array}$ & $\begin{array}{l}\text { below- } \\
\text { ground }\end{array}$ & $\begin{array}{l}\text { below- } \\
\text { ground }\end{array}$ & $\begin{array}{l}\text { below- } \\
\text { ground }\end{array}$ \\
\hline $\begin{array}{l}\text { inter- } \\
\text { action } \\
\text { only }\end{array}$ & $\begin{array}{l}\text { inter- } \\
\text { action } \\
\text { only }\end{array}$ & $\begin{array}{l}\text { inter- } \\
\text { action } \\
\text { only }\end{array}$ & $\begin{array}{l}\text { inter- } \\
\text { action } \\
\text { only }\end{array}$ & $\begin{array}{l}\text { inter- } \\
\text { action } \\
\text { only }\end{array}$ & $\begin{array}{l}\text { inter- } \\
\text { action } \\
\text { only }\end{array}$ & $\begin{array}{l}\text { inter- } \\
\text { action } \\
\text { only }\end{array}$ & $\begin{array}{l}\text { inter- } \\
\text { action } \\
\text { only }\end{array}$ & $\begin{array}{l}\text { inter- } \\
\text { action } \\
\text { only }\end{array}$ & $\begin{array}{l}\text { inter- } \\
\text { action } \\
\text { only }\end{array}$ \\
\hline NS & NS & NS & NS & $\mathbf{L}$ & Plot & $\begin{array}{l}13,36 \\
121 \\
\mathrm{~m}^{-2}\end{array}$ & Infertile & $30 \mathrm{~d}$ & $\begin{array}{l}\text { Abutilon } \\
\text { theophrasti }\end{array}$ \\
\hline- & + & + & NS & $\mathbf{L}-$ & Plot & $\begin{array}{l}13,36 \\
121 \\
\mathrm{~m}^{-2}\end{array}$ & fertile & $30 \mathrm{~d}$ & $\begin{array}{l}\text { Abutilon } \\
\text { theophrasti }\end{array}$ \\
\hline UA & UA & + & + & M & $2.06 \mathrm{~L}$ & $\begin{array}{l}1,4 \\
\text { pot }^{-1}\end{array}$ & UA & $42 \mathrm{~d}$ & $\begin{array}{l}\text { Glycine } \\
\max \end{array}$ \\
\hline NS & + & + & + & M & $500 \mathrm{ml}$ & $\begin{array}{l}1,2 \\
\text { pot }^{-1}\end{array}$ & UA & $60 \mathrm{~d}$ & $\begin{array}{l}\text { Pisum } \\
\text { sativum }\end{array}$ \\
\hline NS & + & + & + & M & $13.27 \mathrm{~L}$ & $\begin{array}{l}1,2 \\
\text { pot }^{-1}\end{array}$ & UA & $110 \mathrm{~d}$ & $\begin{array}{l}\text { Glycine } \\
\max \end{array}$ \\
\hline+ & - & - & + & $\mathrm{M}-$ & $2 \mathrm{~L}$ & $\begin{array}{l}1,2 \\
\text { pot }^{-1}\end{array}$ & dry & $50 \mathrm{~d}$ & $\begin{array}{l}\text { Potentilla } \\
\text { recta, } \\
\text { Leu- } \\
\text { canthe- } \\
\text { mum } \\
\text { vulgare }\end{array}$ \\
\hline UA & UA & + & - & $\mathrm{H}$ & $500 \mathrm{ml}$ & $\begin{array}{l}1,4,8, \\
16 \\
\text { pot }^{-1}\end{array}$ & UA & - & $\begin{array}{l}\text { Avena } \\
\text { sativa }\end{array}$ \\
\hline
\end{tabular}




\begin{tabular}{|c|c|c|c|c|c|c|c|c|c|}
\hline NS & NS & NS & - & $\mathbf{H}-$ & $2 \mathrm{~L}$ & $\begin{array}{l}1,2 \\
\text { pot }^{-1}\end{array}$ & wet & $50 \mathrm{~d}$ & $\begin{array}{l}\text { Potentilla } \\
\text { recta, } \\
\text { Leu- } \\
\text { canthe- } \\
\text { mum } \\
\text { vulgare }\end{array}$ \\
\hline UA & UA & NS & - & $\mathrm{H}-$ & Plot & $1 \mathrm{~m}^{-2}$ & UA & $120 \mathrm{~d}$ & $\begin{array}{l}\text { Achillea } \\
\text { mille- } \\
\text { folium } \\
\text { L. et } \\
\text { al. }\end{array}$ \\
\hline $\begin{array}{l}\text { b. Re- } \\
\text { sponse } \\
\text { to } \\
\text { above- } \\
\text { ground } \\
\text { inter- }\end{array}$ & $\begin{array}{l}\text { b. Re- } \\
\text { sponse } \\
\text { to } \\
\text { above- } \\
\text { ground } \\
\text { inter- }\end{array}$ & $\begin{array}{l}\text { b. Re- } \\
\text { sponse } \\
\text { to } \\
\text { above- } \\
\text { ground } \\
\text { inter- }\end{array}$ & $\begin{array}{l}\text { b. Re- } \\
\text { sponse } \\
\text { to } \\
\text { above- } \\
\text { ground } \\
\text { inter- }\end{array}$ & $\begin{array}{l}\text { b. Re- } \\
\text { sponse } \\
\text { to } \\
\text { above- } \\
\text { ground } \\
\text { inter- }\end{array}$ & $\begin{array}{l}\text { b. Re- } \\
\text { sponse } \\
\text { to } \\
\text { above- } \\
\text { ground } \\
\text { inter- }\end{array}$ & $\begin{array}{l}\text { b. Re- } \\
\text { sponse } \\
\text { to } \\
\text { above- } \\
\text { ground } \\
\text { inter- }\end{array}$ & $\begin{array}{l}\text { b. Re- } \\
\text { sponse } \\
\text { to } \\
\text { above- } \\
\text { ground } \\
\text { inter- }\end{array}$ & $\begin{array}{l}\text { b. Re- } \\
\text { sponse } \\
\text { to } \\
\text { above- } \\
\text { ground } \\
\text { inter- }\end{array}$ & $\begin{array}{l}\text { b. Re- } \\
\text { sponse } \\
\text { to } \\
\text { above- } \\
\text { ground } \\
\text { inter- }\end{array}$ \\
\hline $\begin{array}{l}\text { ac- } \\
\text { tion only } \\
\text { (light } \\
\text { quan- } \\
\text { tity } \\
\text { and } \\
\text { qual- } \\
\text { ity } \\
\text { treat- } \\
\text { ments) }\end{array}$ & $\begin{array}{l}\text { ac- } \\
\text { tion only } \\
\text { (light } \\
\text { quan- } \\
\text { tity } \\
\text { and } \\
\text { qual- } \\
\text { ity } \\
\text { treat- } \\
\text { ments) }\end{array}$ & $\begin{array}{l}\text { ac- } \\
\text { tion only } \\
\text { (light } \\
\text { quan- } \\
\text { tity } \\
\text { and } \\
\text { qual- } \\
\text { ity } \\
\text { treat- } \\
\text { ments) }\end{array}$ & $\begin{array}{l}\text { ac- } \\
\text { tion only } \\
\text { (light } \\
\text { quan- } \\
\text { tity } \\
\text { and } \\
\text { qual- } \\
\text { ity } \\
\text { treat- } \\
\text { ments) }\end{array}$ & $\begin{array}{l}\text { ac- } \\
\text { tion only } \\
\text { (light } \\
\text { quan- } \\
\text { tity } \\
\text { and } \\
\text { qual- } \\
\text { ity } \\
\text { treat- } \\
\text { ments) }\end{array}$ & $\begin{array}{l}\text { ac- } \\
\text { tion only } \\
\text { (light } \\
\text { quan- } \\
\text { tity } \\
\text { and } \\
\text { qual- } \\
\text { ity } \\
\text { treat- } \\
\text { ments) }\end{array}$ & $\begin{array}{l}\text { ac- } \\
\text { tion only } \\
\text { (light } \\
\text { quan- } \\
\text { tity } \\
\text { and } \\
\text { qual- } \\
\text { ity } \\
\text { treat- } \\
\text { ments) }\end{array}$ & $\begin{array}{l}\text { ac- } \\
\text { tion only } \\
\text { (light } \\
\text { quan- } \\
\text { tity } \\
\text { and } \\
\text { qual- } \\
\text { ity } \\
\text { treat- } \\
\text { ments) }\end{array}$ & $\begin{array}{l}\text { ac- } \\
\text { tion only } \\
\text { (light } \\
\text { quan- } \\
\text { tity } \\
\text { and } \\
\text { qual- } \\
\text { ity } \\
\text { treat- } \\
\text { ments) }\end{array}$ & $\begin{array}{l}\text { ac- } \\
\text { tion only } \\
\text { (light } \\
\text { quan- } \\
\text { tity } \\
\text { and } \\
\text { qual- } \\
\text { ity } \\
\text { treat- } \\
\text { ments) }\end{array}$ \\
\hline UA & UA & NS & NS & L-M & $516 \mathrm{ml}$ & $\begin{array}{l}0.5,1.9 \\
\mathrm{R}: \mathrm{FR}\end{array}$ & UA & $42 \mathrm{~d}$ & $\begin{array}{l}\text { Glycine } \\
\max \end{array}$ \\
\hline UA & UA & - & NS & $\mathrm{L}-\mathrm{M}-$ & $115 \mathrm{ml}$ & $\begin{array}{l}0.2,1.0 \\
\text { R: FR; } \\
65 \%, \text { full } \\
\text { PAR }\end{array}$ & UA & $80-170 \mathrm{~d}$ & $\begin{array}{l}\text { Acacia } \\
\text { implexa }\end{array}$ \\
\hline UA & UA & - & - & $\mathrm{H}$ & $3 \mathrm{~L}$ & $\begin{array}{l}25,50 \\
75 \\
\% \text { shade }\end{array}$ & $\mathrm{UA}$ & $1-2 y$ & $\begin{array}{l}\text { Picea } \\
\text { sitchen- } \\
\text { sis et } \\
\text { al. }\end{array}$ \\
\hline UA & UA & NS & - & $\mathrm{H}-$ & $3.5 \mathrm{~L}$ & $\begin{array}{l}100 \\
m^{-2}\end{array}$ & UA & $60 \mathrm{~d}$ & Abutilon the \\
\hline
\end{tabular}




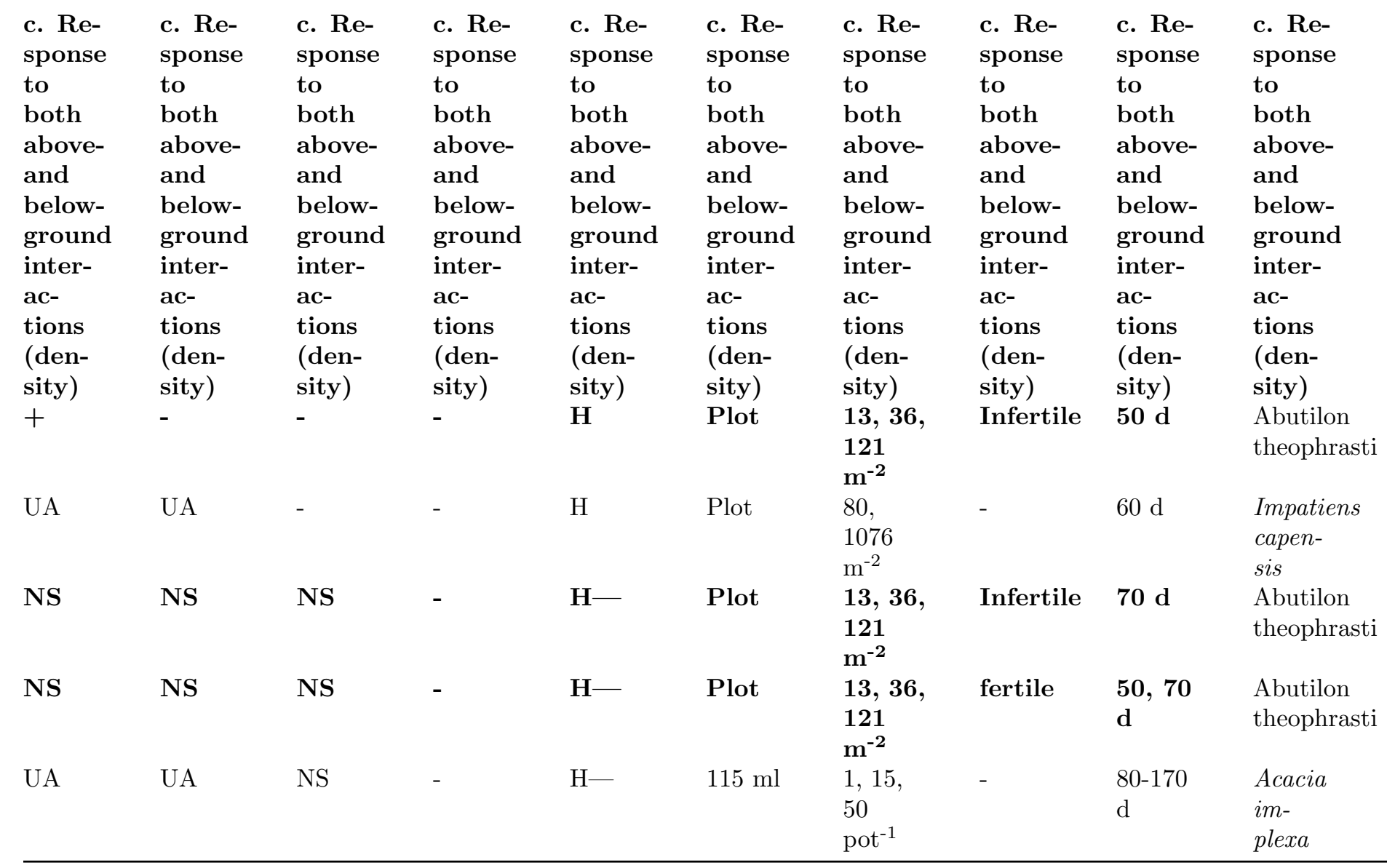

The intensities of above- (Above) and below-ground (Below) interactions were classified into Low (L), moderate $(\mathrm{M})$ and high $(\mathrm{H})$ levels mainly according to the responses of total biomass. Results of the present study were in bold font.

${ }^{\text {a }} \mathrm{NS},+$ and-signify no change, an increase and decrease in root: shoot ratio or root mass ratio in response to competition. UA indicates the relevant information is unavailable.

${ }^{b}$ Size of pots or unrestricted space (UR) in field experiments.

${ }^{c}$ Number of individuals per square meter or pot $\left(\mathrm{m}^{-2}\right.$ or pot $\left.{ }^{-1}\right)$, or light treatments.

Figure legends

Fig. 1. Original (left) and adjusted (right; by removing effects of total mass) mean values ( \pm SE) of plant root mass (grey) and shoot mass (white) at low, medium and high densities in infertile and fertile soil conditions at 30,50 and $70 \mathrm{~d}$ of growth. Different letters denoted significant differences between density treatments $(\mathrm{p}<0.05)$ within each soil condition and stage.

Fig. 2. Original (left) and adjusted (right; by removing effects of total mass) mean values ( \pm SE) of root:shoot ratio for individuals at low (white), medium (grey) and high (black) densities under infertile and fertile soil conditions at 30,50 and $70 \mathrm{~d}$ of growth. Different letters denoted significant differences between density treatments $(\mathrm{p}<0.05)$ within each soil condition and stage.

Fig. 3. Original (left) and adjusted (right; by removing effects of total mass) mean values $( \pm \mathrm{SE})$ of main root diameter (MRD), lateral root length (LRL) and number (LRN) at low (white), medium (gray) and high 
(black) densities under infertile and fertile soil conditions at 50 and $70 \mathrm{~d}$ of growth. Different letters denoted significant differences between density treatments $(\mathrm{p}<0.05)$ within each soil condition and stage.

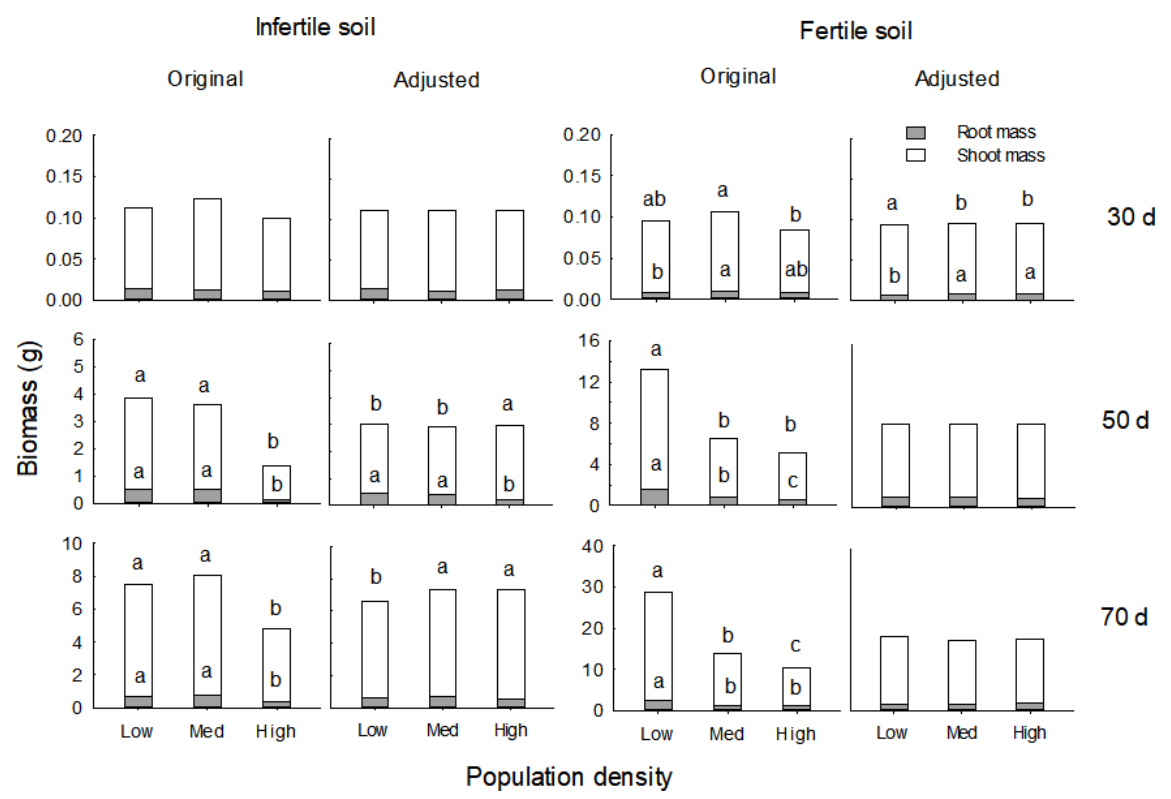



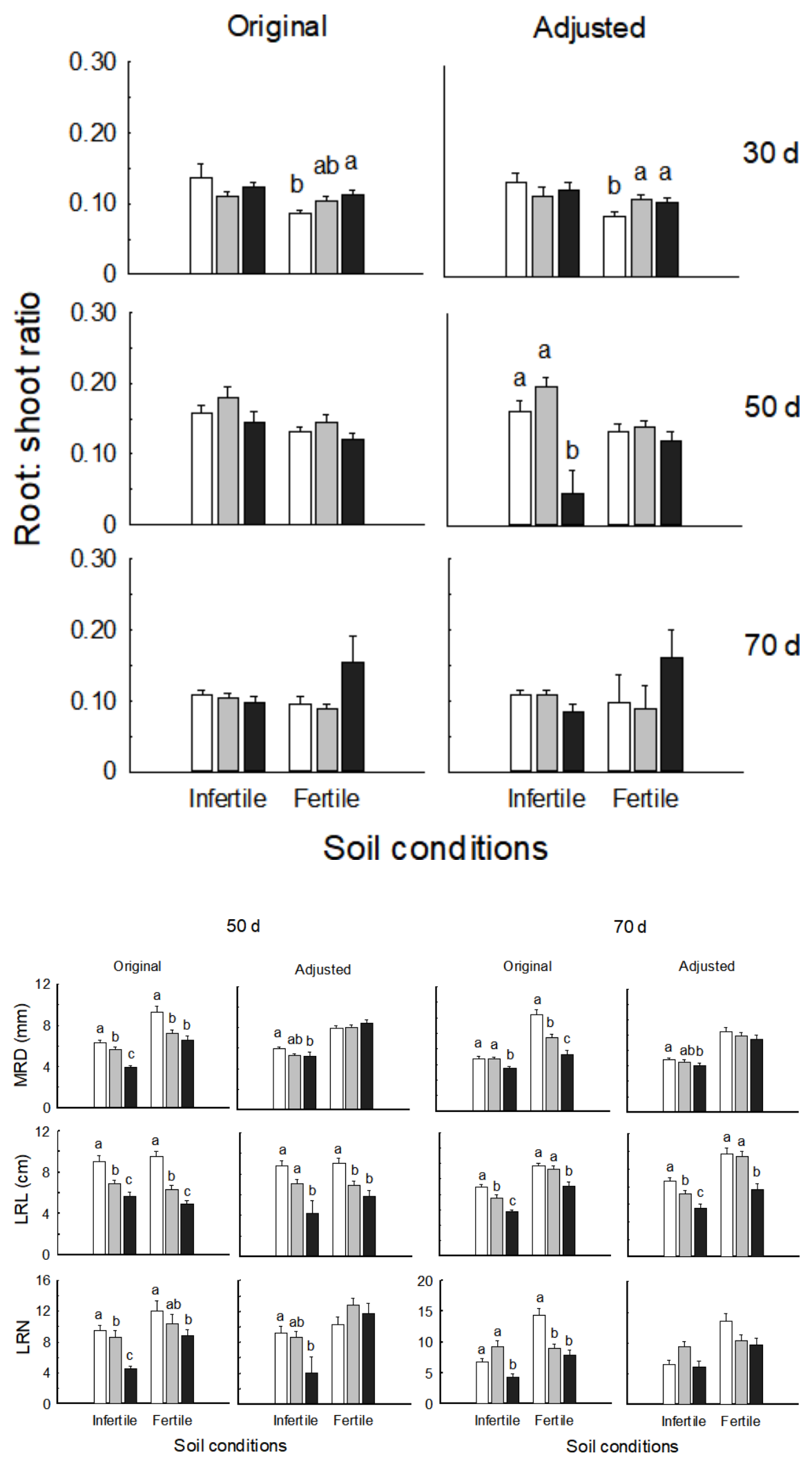